\title{
RECONSTRUCTION OF FOREARM, WRIST AND HAND SKIN DEFECTS WITH LOCAL PERFORATOR FLAPS
}

\author{
Mohammed Mostafa El-Mahy, Ahmed Naeem Atiyya, Ramy Ahmed Diab, \\ Amr Mostafa Aly and, Hassan Abdel Hamid Abdel Fattah
}

Orthopaedics Department, Faculty of medicine, Ain Shams university.

Corresponding author:

Hassan Abdel Hamid AbdelFattah

Mobile: 01007455220

E mail:

d.hassan.abdelhameed11@gmai

1.com,

Received: 16/4/2019

Accepted: 8/5/2019

\section{ABSTRACT:}

Background: During the last decades, anatomical studies on skin vascularization provided the base for the development of flaps nourished by perforating arteries and preserving major vessels.

In the last years, perforator flaps have become an appealing option for coverage of a large range of defects as they allow for great freedom in design and for reconstruction of difficult wounds with minimal donor-site morbidity, but doubts regarding their reliability have overshadowed its safety in clinical practice.

Aim of the Work: This prospective clinical study is conducted to assess the reliability and efficacy of local perforator flaps in coverage of hand, wrist, and forearm skin defects.

Patients and methods: We conducted a prospective study involving 20 patients with hand, wrist, and forearm skin defects and were covered with local radial and ulnar arteries perforator flaps. Postoperative complications were recorded and assessment of patients' satisfaction as regards donor site morbidity and aesthetic outcome of the flap was done by a questionnaire at the outpatient clinic and the results were classified as unsatisfactory, satisfactory, good, and very good. Vancouver Scar Scale was applied as an objective tool for scar assessment postoperative. Three-month follow up was the end point of this study.

Results: Radial artery perforator flaps were done in 11 cases (55\%) and ulnar artery perforator flaps in 9 cases (45\%).Temporary venous congestion happened in 19 cases, distal tip necrosis in 10 cases, superficial epidermolysis in 8 cases, and arterial insufficiency in one case. Mean operative time was $63.8 \mathrm{~min}$., $70.64 \mathrm{~min}$. in RA perforator flaps and $55.44 \mathrm{~min}$. in UA perforator flaps.

Conclusion: Perforator flaps are a reliable tool for upper extremity coverage, with a low rate of failure and secondary surgery. These flaps are particularly useful for covering small and medium sized defects in the distal one third of the forearm, wrist, and hand; and they represent a reliable and effective alternative to free flaps.

Key words: perforator flaps, skin defects, propeller flap, local flap, upper limb reconstruction.

\section{INTRODUCTION:}

The reconstruction of loss of substance due to trauma or oncological excisions has relevant functional and aesthetic implicate- ons. Some kind of flaps used for the treatment of upper and lower limb lesions required the sacrifice of major vascular bundles ${ }^{(1)}$. 
The ultimate choice of soft tissue coverage will depend on the size and site of the wound, complexity of the injury, status of surrounding tissue, exposure of the vital structures and health status of the patient ${ }^{(2)}$.

According to the definition established during the Consensus Conference of Gent in 2003, perforator flaps are constituted by cutaneous and subcutaneous tissue areas nourished by perforator arterial branches originating from major vascular bundles with an intramuscular or intraseptal course $^{(3)}$.

At the forearm, most of the blood supply comes from fasciocutaneous perforators that arise from the radial, ulnar, anterior interosseous, and posterior interosseous arteries. ${ }^{(4)}$

Taylor and Palmer developed the angiosome concept, showing that this represents a block of tissue supplied by a same source artery and vein through branches for all tissues between skin and bone. At the same time, neigh bouring angiosomes are linked to each other via "choke vessels"(5).

The distal third of the forearm has a rich supply of arterial perforators compared with the proximal two thirds of the forearm. ${ }^{(6)}$ Based on experimental studies, Taylor et al. reported that a single perforator may safely supply its proper angiosome and up to the half of vascular territory of the adjacent perforator $^{(7)}$.

The pedicle can be isolated by means of loupes and microscope is normally not required ${ }^{(8)}$. The absence of vascular sutures and the preservation of major vessels are the main advantages of propeller flaps ${ }^{(\mathbf{9})}$. Moreover, from the aesthetic point of view, the reconstruction of the defect can be achieved with optimal results as it takes into account the concept of like-with-like reconstruction by means of donor areas close to that of the defect ${ }^{(9)}$.
There are some possible drawbacks in using these flaps. The most important complications are represented by complete or partial flap loss due to venous problems that may be due to its insufficient dissection and mobilisation, especially around the vein. If compared with free flaps, the loss of a propeller perforator flap, involves generally only partial thickness of the flap. If a free flap is lost, everything is lost, while generally in a propeller perforator flap only the superficial part is lost. This means that the flap has done its job of covering the denuded anatomical elements, because after debridement granulation of the wound is very fast and allows skin grafting ${ }^{(\mathbf{1 0})}$.

\section{AIM OF THE WORK:}

This prospective clinical study is conducted to assess the reliability and efficacy of local perforator flaps in coverage of hand, wrist, and forearm skin defects including operative time and incidence of complications, including venous congestion, distal tip necrosis, superficial epidermolysis, and flap ischemia.

\section{PATIENTS AND METHODS:}

- Study design: prospective clinical study.

- Setting: Ain Shams University Hospitals starting from April 2017 till March 2019.

- After obtaining the hospitals Research/ Ethics Committee approval and written informed consents from the patients, this study was carried on twenty patients, table (1) with distal forearm, wrist, and hand skin defects at Ain Shams university Hospitals.

- All patients were screened for eligibility by detailed clinical assessment of their history and physical examination as well as investigations required and those who met the inclusion criteria were included in this study. 
Table (1): Summary of patients.

\begin{tabular}{|c|c|c|c|c|c|c|c|c|c|c|c|c|}
\hline No & Age & Sex & $\begin{array}{c}\text { Hande-- } \\
\text { dness }\end{array}$ & $\begin{array}{c}\text { Site of skin } \\
\text { defect }\end{array}$ & $\begin{array}{l}\text { Time till } \\
\text { coverage }\end{array}$ & \begin{tabular}{|c|} 
Source \\
vessel
\end{tabular} & $\begin{array}{c}\text { Flap } \\
\text { dimensions }\end{array}$ & $\begin{array}{l}\text { Operative } \\
\text { time }\end{array}$ & Complications.* & \begin{tabular}{|l|} 
Medical \\
disordes
\end{tabular} & Smoking & $\begin{array}{c}\text { Associated } \\
\text { injuries }\end{array}$ \\
\hline 1 & 34 & $\mathrm{M}$ & RT & $\begin{array}{c}\text { RT, Volar wrist } \\
\text { defect }\end{array}$ & $6^{\text {th }}$ week & RA & $3.2 \times 7.7 \mathrm{~cm}$ & $40 \mathrm{~min}$. & - SE, TVC, DTN. & ----------- & yes & $\begin{array}{l}\text { Median nerve } \\
\text { injury }\end{array}$ \\
\hline 2 & 17 & $\mathrm{M}$ & RT & $\begin{array}{c}\text { LT,Dorsum of } \\
\text { hand\&wrist }\end{array}$ & $5^{\text {th }}$ day & UA & $3.2 \times 9.4 \mathrm{~cm}$ & 55 min. & $-\mathrm{TVC}$ & ---------- & No & |-------------------- \\
\hline 3 & 23 & $\mathrm{M}$ & RT & $\begin{array}{l}\text { RT,1st web } \\
\text { space }\end{array}$ & $\begin{array}{c}\text { Elective"2 y } \\
\text { after trauma } \\
\end{array}$ & RA & $2.3 \times 11.3 \mathrm{~cm}$ & $83 \mathrm{~min}$. & -TVC, DTN. & --------- & No & $\begin{array}{c}\text { Both bones } \\
\text { forearm } \\
\text { fracture }\end{array}$ \\
\hline 4 & 62 & $\mathrm{M}$ & RT & $\begin{array}{c}\text { LT,Dorsal } \\
\text { wrist defect }\end{array}$ & $6^{\text {th }}$ week & UA & $3.4 \times 10.3 \mathrm{~cm}$ & 88 min. & -complete necrosis & $\begin{array}{l}\text {-DM\& } \\
\text { HPTN }\end{array}$ & No & $\begin{array}{l}\text { Both bones } \\
\text { forearm fr., } \\
\text { DRUJ } \\
\text { dislocation, } \\
\text { extensor } \\
\text { tendons injury. }\end{array}$ \\
\hline 5 & 27 & M & RT & $\begin{array}{c}\mathrm{LT}, 1^{\mathrm{st}} \\
\text { metacarpal }\end{array}$ & $\begin{array}{l}5^{\text {th }} \text { day of } \\
\text { injury }\end{array}$ & RA & $2.8 \mathrm{X} 11.8 \mathrm{~cm}$ & $53 \mathrm{~min}$. & -SE, TVC, DTN. & ------ & Yes & $\begin{array}{l}\text { Dislocated } \\
1^{\text {st }} \mathrm{MP} \\
\text { joint\&ipsi- } \\
\text {-lateral shaft } \\
\text { humerus } \\
\text { fracture } \\
\end{array}$ \\
\hline 6 & 29 & $\mathrm{M}$ & RT & $\begin{array}{c}\text { LT,Distal } \\
\text { forearm }\end{array}$ & $2^{\text {nd }}$ day & RA & $3.1 \times 8.6 \mathrm{~cm}$ & 48 min.. & $-\mathrm{TVC}$ & |---------- & No & ----------- \\
\hline 7 & 32 & $\mathrm{M}$ & LT & \begin{tabular}{|c|} 
LT,Dorsum of \\
the hand
\end{tabular} & $7^{\text {th }}$ day & RA & $2.5 \times 4.2 \mathrm{~cm}$ & $65 \mathrm{~min}$. & $-\mathrm{TVC}$ & |---------- & yes & $\begin{array}{c}\text { extensor } \\
\text { tendons injury }\end{array}$ \\
\hline 8 & 10 & $\mathrm{~F}$ & RT & $\begin{array}{c}\text { RT, } 1^{\text {st }} \text { web } \\
\text { space }\end{array}$ & $\begin{array}{l}\text { Elective"4 y } \\
\text { after trauma" }\end{array}$ & RA & $2.5 \times 10 \mathrm{~cm}$ & $85 \mathrm{~min}$. & ------- & ------- & No & ------- \\
\hline 9 & 36 & M & RT & $\begin{array}{c}\mathrm{LT}, \text { Dorsum of } \\
\text { hand }\end{array}$ & $5^{\text {th }}$ day & UA & $3.1 \times 9.6 \mathrm{~cm}$ & $77 \mathrm{~min}$. & $-\mathrm{TVC}$ & -DM & yes & $\begin{array}{c}\text { extensor } \\
\text { tendons } \\
\text { injury }\end{array}$ \\
\hline 10 & 38 & $\mathrm{M}$ & RT & \begin{tabular}{|c|} 
RT,Dorsum of \\
hand \&wrist
\end{tabular} & $6^{\text {th }}$ day & RA & $3.2 \times 6.1 \mathrm{~cm}$ & 70 min. & - SE, TVC, DTN. & -HPTN & Yes & ------- \\
\hline 11 & 39 & $\mathrm{M}$ & RT & \begin{tabular}{|c|} 
RT,Dorsum of \\
hand \&wrist
\end{tabular} & $2^{\text {nd }}$ day & RA & $2.7 \times 4.7 \mathrm{~cm}$ & $85 \mathrm{~min}$. & $-\mathrm{TVC}$ & -------- & No & -------------' \\
\hline 12 & 40 & $\mathrm{M}$ & RT & $\begin{array}{c}\text { RT,Dorsum of } \\
\text { hand }\end{array}$ & 6th day & RA & $2.3 \times 9.1 \mathrm{~cm}$ & $73 \mathrm{~min}$. & - TVC, DTN. & ----------- & yes & $\begin{array}{c}\text { extensor } \\
\text { tendons } \\
\text { injury }\end{array}$ \\
\hline 13 & 41 & $\mathrm{~F}$ & RT & $\begin{array}{c}\text { RT,Distal } \\
\text { volar forearm }\end{array}$ & $6^{\text {th }}$ day & RA & $2.9 \times 10.4 \mathrm{~cm}$ & $43 \mathrm{~min}$. & -TVC, DTN & ---- & No & $\begin{array}{c}\text { Distal radius } \\
\text { fracture,FCU } \\
\text { injury } \\
\end{array}$ \\
\hline 14 & 42 & M & RT & $\begin{array}{c}\text { LT,Dorsum of } \\
\text { hand\&wrist }\end{array}$ & $6^{\text {th }}$ day & UA & $2.6 \times 10 \mathrm{~cm}$ & $55 \mathrm{~min}$. & - SE, TVC, DTN. & $\begin{array}{l}\text {-DM\& } \\
\text { HPTN }\end{array}$ & yes & \begin{tabular}{|c|} 
Both bones \\
forearm, metacar \\
-pal fracture, \\
extensor \\
tendons injury.
\end{tabular} \\
\hline 15 & 43 & $\mathrm{M}$ & RT & \begin{tabular}{|c|} 
RT,Dorsum of \\
hand \&wrist
\end{tabular} & $6^{\text {th }}$ day & UA & $2.7 \times 6.8 \mathrm{~cm}$ & $50 \mathrm{~min}$. & -- SE, TVC, DTN. & -HPTN & NO & $\begin{array}{c}\text { Distal radius } \\
\text { fracture }\end{array}$ \\
\hline 16 & 45 & $\mathrm{M}$ & RT & $\begin{array}{c}\mathrm{LT}, \text { Dorsum of } \\
\text { hand }\end{array}$ & $1^{\text {st }}$ day & UA & $3.3 \times 7.3 \mathrm{~cm}$ & $47 \mathrm{~min}$. & $-\mathrm{TVC}$ & $-\mathrm{DM}$ & yes & $\begin{array}{c}\text { Extensor } \\
\text { tendons } \\
\text { injury } \\
\end{array}$ \\
\hline 17 & 48 & $\mathrm{M}$ & RT & $\begin{array}{c}\text { RT,Dorsum of } \\
\text { hand }\end{array}$ & $7^{\text {th }}$ day & RA & $2.3 \times 5.2 \mathrm{~cm}$ & $90 \mathrm{~min}$. & -- SE, TVC, DTN. & $\begin{array}{l}-\mathrm{DM} \& \\
\text { HPTN }\end{array}$ & No & $\begin{array}{c}\text { extensor } \\
\text { tendons } \\
\text { injury }\end{array}$ \\
\hline 18 & 50 & $\mathrm{~F}$ & RT & $\begin{array}{c}\text { RT,Dorsum of } \\
\text { hand }\end{array}$ & $\begin{array}{c}\text { Elective" } 1 \\
\text { y." }\end{array}$ & UA & $3.3 \times 4 \mathrm{~cm}$ & 40 min. & -- SE, TVC. & $\begin{array}{l}\text {-DM\& } \\
\text { HPTN }\end{array}$ & No & ----- \\
\hline 19 & 55 & $\mathrm{M}$ & RT & $\begin{array}{l}\text { LT,1st web } \\
\text { space }\end{array}$ & $6^{\text {th }}$ day & UA & $2.9 \times 9.5 \mathrm{~cm}$ & $85 \mathrm{~min}$. & -- SE, TVC, DTN. & -HPTN & No & ------ \\
\hline 20 & 23 & $\mathrm{M}$ & RT & $\begin{array}{c}\text { RT,Dorsum of } \\
\text { hand }\end{array}$ & 5th day & UA & $2.7 \mathrm{X} 8.3 \mathrm{~cm}$ & 44 min. & $-\mathrm{TVC}$ & -------- & yes & ------- \\
\hline
\end{tabular}

*TVC: Temporary venous congestion, DTN:

distal tip necrosis, SE: superficial epidermolysis. 


\section{Inclusion Criteria:}

- Patients with skin defects at distal forearm, wrist, and hand proximal to the base of proximal phalanges.

- Defects less than $10 \times 20 \mathrm{~cm}$.

\section{Exclusion Criteria:}

- Defects distal to the base of proximal phalanges.

- Patients with trauma to the distal forearm that may have damaged the perforators.

- Patients with defects greater than $10 \mathrm{~cm}$ $\mathrm{x} 20 \mathrm{~cm}$.

- History of venous insufficiency or thrombosis in the affected limb.

- Skin defects amenable to be covered by skin grafts.

- Extensive trauma zone, associated multiple fractures of the extremity at or adjacent to the level of the defect.

All patients were subjected to the following:

\section{Surgical technique:}

- The patient was placed supine on the operating table and brachial tourniquet was applied and operative start time was documented.

- After appropriate debridement of the soft tissue and management of associated injuries, the size and location of the defect were noted, determination of the main source artery which was closer to the skin defect to minimize the flap dimensions.

- One incision, on one edge of the future flap was performed, starting from the radial side in cases of radial artery perforator flap and the ulnar side in cases of ulnar artery perforator flap. Under loupe magnification and blunt dissection, all the perforators were identified. Once all perforators have been identified, the best one was chosen based on caliber, proximity to the defect, pulsatility, course, orientation, and caliber of accompanying veins.

\section{Preoperative evaluation:}

\section{History:}

- An accurate history was taken regarding mode of trauma, time of trauma, and any previous vascular morbidities

- Patients were also asked about prior surgical procedures, infections, medications, medical history, and family history.

\section{Examination:}

General examination was done especially in polytraumatized patients (5 cases, $25 \%$ ) to check vital data and patient stabilization and to exclude other injuries, all cases were vitally stable with no extraskeletal injury.

Local examination included site and size of the soft tissue defect, bone fractures, tendon injuries, and neurovascular assessment for associated arterial, venous, and peripheral nerve injuries

- The remaining part of the skin incision was made after marking the length and width of the flap according to size and site of the skin defect and the pivot point related to the perforator; then the flap was raised from a proximal to distal direction as far as the distal pivot point.

- Then, skin incision was done between the pivot point and the recipient site, once the flap was islanded, tourniquet was released and flap was permitted to perfuse for a while before rotation, after rotation or advancement, the viability of the flap was reassessed for color, capillary refilling, and bleeding.

- Direct primary closure of the donor site without tension was performed, skin graft was not needed in all cases.

\section{Postoperative:}

- Adequate hydration of the patient, appropriate pain control measures.

- Sequential clinical examinations of the flap for arterial insufficiency and 
venous congestion, patient typically stays in the hospital for 2 to 3 days before being discharged but 12 cases with associated injuries required longer admission.

\section{Follow up (outcome):}

- Patients were assessed at one, two, four and twelve weeks post operatively by clinical evaluation as regards flap survival and donor site morbidities and three-month follow up was the end point of this study.

- Assessment of patients' satisfaction as regards donor site morbidity and aesthetic outcome of the flap was done by a questionnaire at the outpatient clinic.

- Vancouver Scar Scale ${ }^{(11)}$ was applied to assess scarring postoperative as an objective tool because the patients' perception of their scars is not factored in to the overall score, but it assesses 4 variables: vascularity, height/thickness, pliability, and pigmentation, table (2).

\section{RESULTS}

- $\quad$ From April 2017 to March 2019, twenty patients with distal forearm, wrist, and hand skin defects met the inclusion criteria and were covered by local perforator flap based on perforators from radial and ulnar arteries.

- The patients were distributed demographically as 17 males $(80 \%)$ and 3 females (20\%), their age ranged from $10-62$ yrs. with a mean age of 36.8 yrs.

- All the patients were right handed except 2 patients $(10 \%)$ and the injuries were in the right side in 11 patients $(55 \%)$ and in the left side in 9 patients $(45 \%)$.

- Size of the skin flap ranged from $2.3 \times 5.2 \mathrm{~cm}$ to $3.4 \times 10.3 \mathrm{~cm}$ with average $3.01 \times 8.21 \mathrm{~cm}$.

Table (2): The Vancouver scar scale. ${ }^{(11)}$

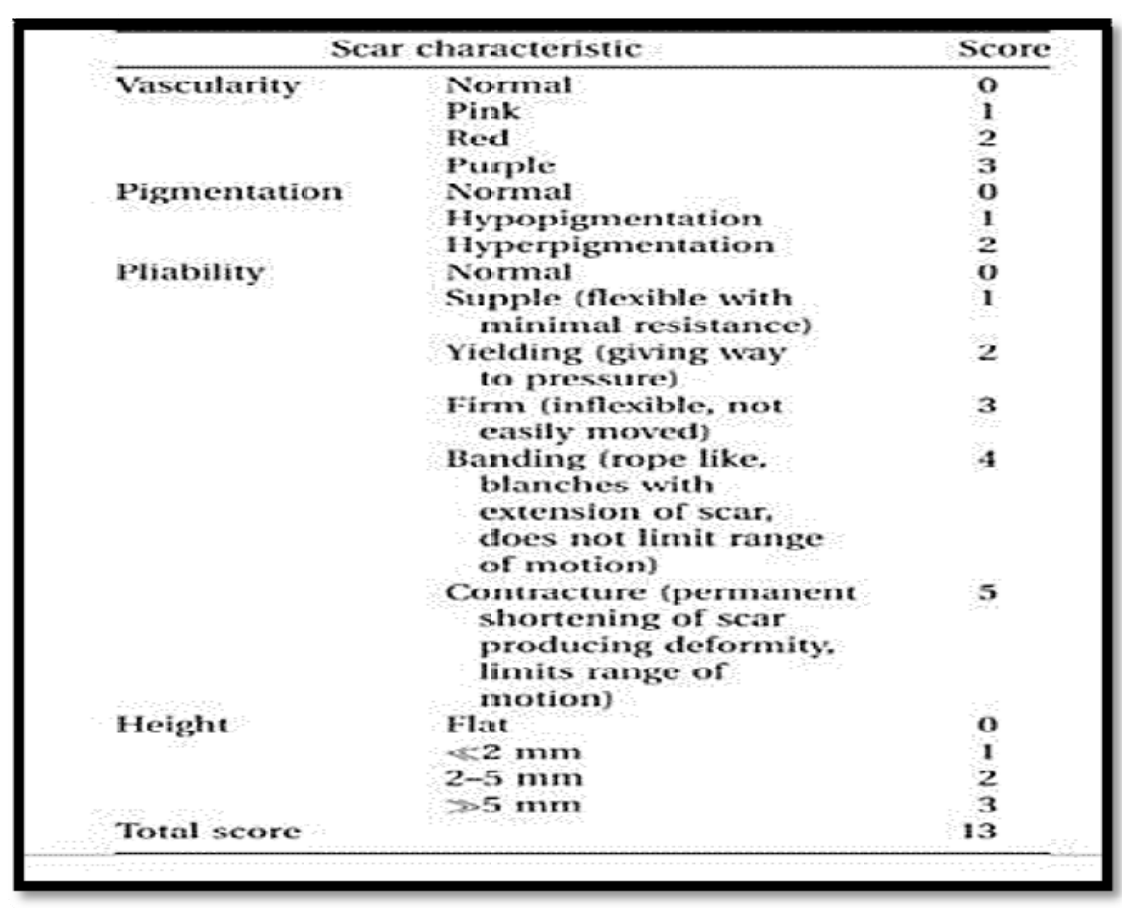


Diagram (1): The overall complications and rate of incidence.

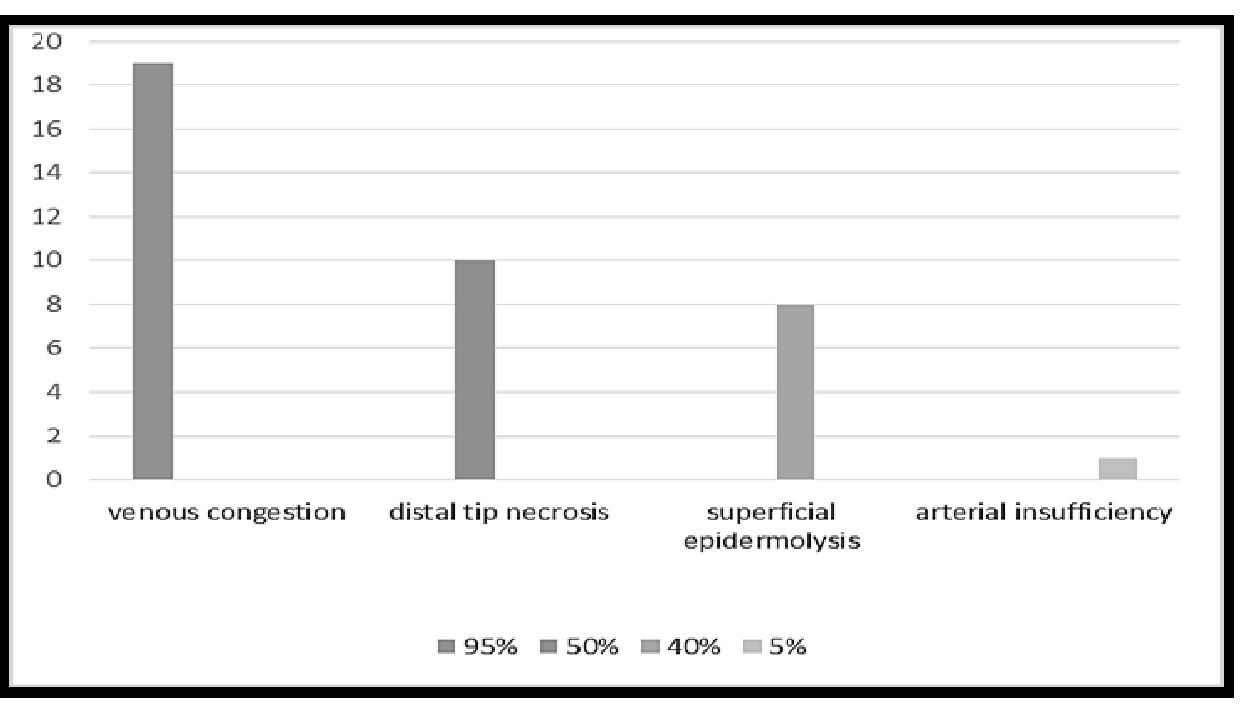

Table (3): Patients' satisfaction as regards postoperative outcomes.

\begin{tabular}{|c|c|c|c|c|c|c|c|c|}
\hline cases & \multicolumn{2}{|c|}{ unsatisfactory } & \multicolumn{2}{|c|}{ satisfactory } & \multicolumn{2}{|c|}{ good } & \multicolumn{2}{c|}{ very good } \\
\hline outcome & No. & $\%$ & No. & $\%$ & No. & $\%$ & No. & $\%$ \\
\cline { 2 - 10 } Donor site morbidity & 0 & $0 \%$ & 4 & $20 \%$ & 8 & $40 \%$ & 8 & $40 \%$ \\
\hline Aesthetic outcome of the flap & 4 & $20 \%$ & 8 & $40 \&$ & 4 & $20 \%$ & 4 & $20 \%$ \\
\hline
\end{tabular}

The mean Vancouver Scar Scale was 5.15, two cases had a score: 2, one case had a score: 3, seven cases had a score: 4, 4 cases had a score: 5 , three cases had a score:7, three cases had a score:9.

Table (4): Relation between patients' factors; age, smoking, medical disorders and incidence of complications.

\begin{tabular}{|c|c|c|c|c|c|c|}
\hline \multirow[b]{2}{*}{ Patients' factors } & \multirow[b]{2}{*}{$\begin{array}{c}\text { NO. } \\
\text { Of } \\
\text { Cases, (\%) }\end{array}$} & \multicolumn{3}{|c|}{ Complications } & \multicolumn{2}{|c|}{ Chi-square test } \\
\hline & & $\begin{array}{c}\text { Temporary } \\
\text { venous } \\
\text { congestion }\end{array}$ & $\begin{array}{c}\text { Superficial } \\
\text { epidermolysis }\end{array}$ & $\begin{array}{c}\text { Distal tip } \\
\text { necrosis }\end{array}$ & $x^{2}$ & $\begin{array}{c}\mathrm{p}- \\
\text { value }\end{array}$ \\
\hline $\begin{array}{c}\text { Age: } \\
-10: 29 \mathrm{y} . \\
-30: 49 \mathrm{y} . \\
-50: 69 \mathrm{y} .\end{array}$ & $\begin{array}{l}6(30 \%) \\
11(55 \%) \\
3 *(15 \%)\end{array}$ & $\begin{array}{c}5(83.3) \\
11(100 \%) \\
2(66.6 \%) \\
\end{array}$ & $\begin{array}{l}1(16.7 \%) \\
5(45.4 \%) \\
2(66.6 \%)\end{array}$ & $\begin{array}{l}2(33.3 \%) \\
6(54.5 \%) \\
2(66.6 \%)\end{array}$ & 1.350 & 0.857 \\
\hline $\begin{array}{c}\text { Smoking: } \\
\text {-smokers } \\
\text {-non smokers }\end{array}$ & $\begin{array}{l}9(45 \%) \\
11(55 \%)\end{array}$ & $\begin{array}{c}9(100 \%) \\
10(90.9 \%)\end{array}$ & $\begin{array}{l}4(44.4 \%) \\
4(36.4 \%)\end{array}$ & $\begin{array}{l}5(55.5 \%) \\
5(45.5 \%)\end{array}$ & 0.026 & 0.987 \\
\hline $\begin{array}{c}\text { Medical } \\
\text { disorders: } \\
\text {-diabetics } \\
\text {-non diabetics }\end{array}$ & $\begin{array}{l}6 \quad(30 \%) \\
14(70 \%)\end{array}$ & $\begin{array}{c}6(100 \%) \\
13(92.8 \%)\end{array}$ & $\begin{array}{c}3(50 \%) \\
5(35.7 \%)\end{array}$ & $\begin{array}{l}3(50 \%) \\
7(50 \%)\end{array}$ & 0.127 & 0.938 \\
\hline $\begin{array}{c}\text {-hypertensive } \\
\text {-non hypertensive }\end{array}$ & $\begin{array}{c}7(35 \%) \\
13(65 \%)\end{array}$ & $\begin{array}{c}7(100 \%) \\
12(92.3 \%)\end{array}$ & $\begin{array}{l}5(71.4 \%) \\
3(23.1 \%)\end{array}$ & $\begin{array}{l}5(71.4 \%) \\
5(38.5 \%)\end{array}$ & 1.583 & 0.453 \\
\hline
\end{tabular}

\section{p-value $>0.05 \mathrm{NS}$}

*Arterial insufficiency happened in one case with complete flap necrosis. 
Table (5): Relation between mode of injury, associated injuries, interval between trauma and coverage and incidence of complications.

\begin{tabular}{|c|c|c|c|c|c|c|}
\hline \multirow{2}{*}{$\begin{array}{l}\text { Trauma } \\
\text { Factors }\end{array}$} & \multirow{2}{*}{$\begin{array}{c}\text { NO. } \\
\text { Of } \\
\text { Cases, }(\%)\end{array}$} & \multicolumn{3}{|c|}{ Complications* } & \multicolumn{2}{|c|}{$\begin{array}{c}\text { Chi-square } \\
\text { test }\end{array}$} \\
\hline & & $\begin{array}{l}\text { Temporary } \\
\text { venous } \\
\text { congestion } \\
\end{array}$ & $\begin{array}{c}\text { Superficial } \\
\text { epidermolysis }\end{array}$ & $\begin{array}{c}\text { Distal tip } \\
\text { necrosis }\end{array}$ & $x^{2}$ & $\begin{array}{c}\text { p- } \\
\text { value }\end{array}$ \\
\hline $\begin{array}{l}\text { Mode of injury: } \\
\text { - Crushing } \\
\text { - Sharp } \\
\text { - Post contracture release }\end{array}$ & $\begin{array}{ll}14 & (70 \%) \\
3 & (15 \%) \\
3 & (15 \%) \\
\end{array}$ & $\begin{array}{ll}14 & (100 \%) \\
3 & (100 \%) \\
2 & (66.6 \%) \\
\end{array}$ & $\begin{array}{c}7(50 \%) \\
1(33.3 \%) \\
0(0 \%) \\
\end{array}$ & $\begin{array}{l}8(57.1 \%) \\
1(33.3 \%) \\
1(33.3 \%) \\
\end{array}$ & 1.142 & 0.888 \\
\hline $\begin{array}{l}\text { Associated injuries: } \\
\text {-Present } \\
\text {-Absent } \\
\end{array}$ & $\begin{array}{l}12(60 \%) \\
8 \quad(40 \%)\end{array}$ & $\begin{array}{l}12(100 \%) \\
7 \quad(87.5 \%) \\
\end{array}$ & $\begin{array}{l}6(50 \%) \\
2(25 \%) \\
\end{array}$ & $\begin{array}{l}5(41.6 \%) \\
5(62.5 \%) \\
\end{array}$ & 1.197 & 0.549 \\
\hline $\begin{array}{l}\text { Interval bet. trauma and } \\
\text { coverage: } \\
-1^{\text {st }} 48 \text { hours } \\
- \text { Bet. } 5^{\text {th }} \& 10^{\text {th }} \text { day of injury } \\
-6 \text { weeks after trauma } \\
\text {-Elective"1-4y }\end{array}$ & $\begin{array}{c}3(15 \%) \\
12(60 \%) \\
2(10 \%) \\
3(15 \%) \\
\end{array}$ & $\begin{array}{c}3(100 \%) \\
12(100 \%) \\
2(100 \%) \\
2(66.6 \%) \\
\end{array}$ & $\begin{array}{c}1(33.3 \%) \\
6(50 \%) \\
1(50 \%) \\
0(0 \%) \\
\end{array}$ & $\begin{array}{l}1(33.3 \%) \\
7(58.3 \%) \\
1(50 \%) \\
1(33.3 \%) \\
\end{array}$ & 1.158 & 0.979 \\
\hline
\end{tabular}

p-value $>0.05$ NS

Table (6): Relation between source artery and incidence of complications and mean operative time in minutes.

\begin{tabular}{|c|c|c|c|c|c|c|c|}
\hline \multirow{2}{*}{$\begin{array}{c}\text { Source } \\
\text { artery }\end{array}$} & $\begin{array}{c}\text { No. } \\
\text { Of } \\
\text { Cases }\end{array}$ & $\begin{array}{c}\text { Temporary } \\
\text { venous } \\
\text { congestion }\end{array}$ & $\begin{array}{c}\text { Superficial } \\
\text { epidermolysis }\end{array}$ & $\begin{array}{c}\text { Distal tip } \\
\text { necrosis }\end{array}$ & $\mathrm{x}^{2}$ & $\begin{array}{c}\mathrm{p}- \\
\text { value }\end{array}$ & $\begin{array}{c}\text { Mean } \\
\text { Operative } \\
\text { time(mean) }\end{array}$ \\
\hline Radial art. & $11(55 \%)$ & $10(90.9 \%)$ & $4(36.4 \%)$ & $7(63.6 \%)$ & 0.995 & 0.608 & $70.64 \pm 12.01$ \\
Ulnar art. & $9(45 \%)$ & $9(100 \%)$ & $4(44.4 \%)$ & $3(33.3 \%)$ & & & $55.44 \pm 9.42$ \\
\hline
\end{tabular}

\section{p-value $>0.05$ NS}

This table shows statistically significant increase mean of radial art., compared to ulnar art., according to mean of operative time, using Independent Sample t-test $\left(t=3.093\right.$; with $p$-value $\left.0.006^{*}\right)$.

\section{DISCUSSION:}

A perforator-based flap can be designed on any perforator, ${ }^{(12)}$ but in this study it was based on distal perforators arising from either the radial or ulnar arteries to cover skin defects in distal forearm, wrist, and hand.

In this study most of the defects were related to trauma-induced injuries or postcontracture release but clinical experience with perforator flaps included coverage of defects after tumor resection, chronic infection, pressure sores, and chronic ulcers $^{(13)}$.

This study included twenty patients of different age groups and occupations with different sizes of the defects and the flap achieved the goal of skin coverage in most of them with an acceptable rate of complications.

The vascularization of the skin has been the topic of several anatomical researches that allowed the development of reconstructive techniques based on local flap nourished by cutaneous perforator $\operatorname{arteries}^{(14)}$, Saint-Cyr et al. ${ }^{(1)}$ have mapped out the territory perfused by a single perforator by carrying out static and dynamic dye injection studies in fresh cadavers. They studied the radial artery, ulnar artery, and dorsal metacarpal artery perforator flaps in the upper limb. They 
introduced the concept of a perforasome (unique vascular territory supplied by a single perforator) and determined that the vascular axis of perforator flaps should follow the axial alignment of the linking vessels, which in turn follows the axial anatomy of the limb. When a flap includes two perforasomes, the link vessels open up to perfuse the flap from a single perforator. This is analogous to the choke vessel concept proposed by Taylor et al. ${ }^{(15)}$, so this study respected this axial pattern of supply during harvest of the flap and it was never designed to be taken with the transeverse axis of the forearm but with the longitudinal axis.

Ono et al. felt that an empty vessel is more susceptible to kinking as compared to a vessel with flow, and they attempt clockwise and counterclockwise rotation of flap to select the direction of rotation before release of the tourniquet. When a rotation has been selected, they put the flap back in its native position. They do the actual rotation after release of the tourniquet ${ }^{(16)}$ we followed this in all cases and the tourniquet was released before rotation to allow filling of the perforator and check flap perfusion.

The perforasome theory based on the mechanism of opening of "potential" vascular territories by means of linking vessels after ligation of adjacent perforators, provides a logical explanation of the sequence of events that ultimately guarantee a sufficient blood supply to the skin far beyond the anatomic territory belonging to any given perforator, however; the dimensional limit of a safe flap is difficult to study in a cadaveric model because the recruitment of adjacent angiosomes is a dynamic phenomenon that should be studied in vivo. For this reason, it is difficult or impossible to predict with certainty the size of the cutaneous area vascularized by one perforator ${ }^{(1)}$. The largest flap dimensions recorded in this study were $2.8 \times 11.8 \mathrm{~cm}$ and it had a good outcome (table 1), the largest flap dimensions that survived and was mentioned in the literature were $8 \mathrm{~cm} \mathrm{x}$ $18 \mathrm{~cm}$ as described by Andrew and James $^{(17)}$.

Thomsen et al retrospectively reviewed the charts of 34 patients reconstructed using 34 pedicled perforator flaps for moderatesized defects of the neck, abdomen, and extremities. The flap size varied from $1.5 \times 3$ $\mathrm{cm}$ to $12 \times 22 \mathrm{~cm}$, the reconstructive goals were achieved in all cases without any total flap loss or major complications ${ }^{(18)}$.

A comprehensive literature review for articles published from January 1991 to December 2011 was performed by Zhang et al. (19) two hundred ninety-five perforator flaps were reported to have been used in a total of 283 patients. Direct closure of the donor site was achieved in 53 cases and with a skin graft in 4 cases. In the other 42 cases, these data were not available ${ }^{(20)}$. In this study direct primary closure of the donor site without tension was performed and skin graft was not needed in all cases, as described by Andrew and James ${ }^{(17)}$, if the width of the donor site defect was less than 3 $\mathrm{cm}$, primary closure could be done. In addition, literature review suggests that linear closure of the donor defect in smaller defects could be made possible by the propeller design of the flap, which on rotation brings the bridge segment of the flap into the donor defect, making closure easier $^{(20)}$.

In the upper limb the reconstruction of loss of substance with propeller flap may offer, together with functional recovery, an optimal aesthetic result due to a like-withlike tissue repair ${ }^{(16)}$.

For reconstruction, early use of a flap with single-stage procedure that can provide well-vascularized flap coverage offers the best possible functional results with early rehabilitation, decreasing morbidity and hospital stay .Free flaps offer flexibility in size, shape, and positioning but are limited 
with regard to donor site morbidity and the need for a facility of microsurgery. Distant flaps including groin, inferior hypogastric and abdominal flaps provide enough tissue for reconstruction but require multiple-stage operations involving prolonged immobilization, increased morbidity and hospital stay. They are also bulky with suboptimal color match $^{(16)}$. Pedicled perforator flaps are thin, which is not always the case with free flaps. This is particularly important when treating defects in the distal lower leg, forearm, and hand ${ }^{(20)}$.

Ignatiadis et al. (21) demonstrated the aesthetic outcome of perforator flaps based on distal ulnar or radial artery perforators, in a series of 23 patients with severe hand injuries and soft tissue defects requiring coverage. Mean follow up was 6 months. The donor and the recipient sites cosmetic results were very good in 13 patients, $56.53 \%$, and satisfactory in the remaining, $43.47 \%$, in this study we assessed patients' satisfaction regarding donor site morbidity and aesthetic outcome of the flap as two separate items as shown in table (3) and we gave the patients 4 choices in the questionnaire and the results were shown in the table.

Radial artery perforator flap was done in 11 cases $(55 \%)$ with mean operative time 70.64 minutes, table (3), and ulnar artery perforator flap was done in 9 cases $(45 \%)$ with mean operative time 55.44 minutes, but most of RA perforator flaps were done near to the beginning of the study that may be the cause of longer operative time that decreased later on after more cases were done.

The time needed for the operation is remarkably shorter than that of a free flap. A pedicled perforator flap is a one-team operation and can usually be done under regional anaesthesia. That is why these operations can be done with smaller resources and for medically more compromised patients than free flap surgery. (20) We needed only 43 minutes in some cases and the average time in our cases was 63.8 minutes, which is shorter than recorded by Mahmoud WH in his study (80 mins) $)^{(22)}$, his study was done on patients admitted between July 2011 and July 2013, this may be indicative of shorter operative time as the flap gained more popularity with time.

Arterial insufficiency is extremely rare and accurate planning of the flap and choice of the perforator help could prevent it. When, due to persistence of arterial spasm, the flap remains pale due to insufficient arterial inflow, the flap can be derotated to its original position for a few days before rotating it $^{(23)}$, in this study, ischemia and complete necrosis happened in one case " $5 \%$ " and followed by healing by secondary intension and happened in the postoperative period, many risk factors were present as the patient was 62 years old, diabetic, hypertensive, and the injury was crushing, otherwise no intraoperative persistent ischemia happened in the study, this percent is very close to that mentioned by Vitse et al. (24) in their systematic literature review, $3 \%$ was incidence of complete necrosis in the final analysis that included ten relevant articles involving 117 flaps.

Venous congestion is the most frequent complication of propeller flaps, because veins are more prone to torsion than arteries. (16) Temporary venous congestion occurred in 19 cases in our study "95\%" and removal of the less important sutures relieved the tension on the flap in cases of progressive congestion.

Venous insufficiency should be distinguished from the temporary congestion that often characterizes perforator flaps and fades out with stabilization of flow. True venous insufficiency worsens with time and should be promptly recognized and treated. When it is limited to an apical part of the flap, its evolution is observed. A small number of cases evolve in necrosis, which is usually superficial, so that deep vital tissue 
is still present at the recipient site. ${ }^{(25)}$ Cases of mild venous congestions in thin flaps can be addressed with leech therapy ${ }^{(23)}$ but it was not available during our study and was not used.

When venous congestion is significant and worsens over time, re-exploration and venous supercharging are the best option, in case a superficial or perforating vein of the flap was prepared during dissection. If venous supercharging is not feasible, an alternative option is to temporarily derotate the flap (a few days) to relieve torsion on the pedicle and let the circulation settle ${ }^{(26)}$ but we did not need to do this during the study, Vitse et al. ${ }^{(24)}$ in their systematic literature review, mentioned $7 \%$ incidence rate of progressive venous congestion in the final analysis that included ten relevant articles involving 117 flaps.

Distal tip necrosis happened in 10 cases, (50\%) and ranged from $3 \mathrm{~mm}$ to $7 \mathrm{~mm}$ and was not clinically significant and was often limited to the skin. After eschar removal, an adequate bed for a skin graft is often present but we preferred healing by secondary intention as another alternative ${ }^{(23)}$ as we did not need skin graft for the donor site in all cases.

Only one case of distal tip necrosis happened in sixteen perforator flaps done by Panse et al. ${ }^{(26)}$ for post-burn reconstruction for various areas of body including wrist and fingers and healed secondarily ${ }^{(27)}$, in comparison, this study had a higher incidence that may be attributed to the difference in mode of injury, this study included 14 cases of crushing injury and only 3 cases of defects developed after release of post-traumatic or post-burn wound contracture.

Superficial epidermolysis happened in 8 cases (40\%), and was followed by spontaneous resolution and was generally acceptable.
Artiaco et al. ${ }^{(3)}$ reported one case of superficial epidermolysis $(14.2 \%)$ that spontaneously healed in seven cases of perforator flaps for the treatment of loss of substance of the upper limbs and was not clinically significant.

The patients were classified in this study according to age into 3 groups as shown in table (4), there was no difference as regards incidence of temporary venous congestion because the overall incidene was $95 \%$, but both superficial epidermolysis and distal tip necrosis were higher in the older age group $(66.6 \%) \&(66.6 \%)$ in comparison to the younger age group (16.7\%) \& (33.3\%) respectively, even the case in which complete flap necrosis happened was related to the older age group, case no. 4 in table (1). Superficial epidermolysis and distal tip necrosis had a higher incidence rate among smokers $(44.4 \%) \&(55.5 \%)$ than nonsmokers $(36.4 \%) \&(45.5 \%)$ respectively, also in hypertensives $(71.4 \%) \&(71.4 \%)$ than non hypertensives $(23.1 \%) \&(38.5 \%)$ respectively. Diabetics did not have a significant higher incidence of superficial epidermolysis and distal tip necrosis $(50 \%)$ \& $(50 \%)$ than nondiabetics $(35.7 \%)$ \& (50\%) respectively.

Superficial epidermolysis did not happen in any cases of post contracture release but in $50 \%$ of cases with crushing injury and in $33.3 \%$ of cases with sharp injury. Associated injuries had 50\% incidence of superficial epidermolysis in comparison to absence of associated injuries which had $25 \%$ incidence only, but distal tip necrosis was less in presence of associated injuries $(41.6 \%)$ in comparison to absence of associated injuries (62.5\%).Elective cases and cases which were done in $1^{\text {st }} 48$ hours after trauma have nearly equal incidence rate of both superficial epidermolysis and distal tip necrosis as shown in table (5), also cases which were done between $5^{\text {th }}$ and $10^{\text {th }}$ day of injury and cases which were done 6 weeks after trauma have nearly equal incidence rate 
of both superficial epidermolysis and distal tip necrosis as shown in the table.

The differences in incidence rates of different types of complications in relation to patients' factors or factors related to trauma were found to be not statistically significant using Independent Sample t-test with p-value as shown in table (4) and (5).

To the best of our knowledge, this study is the first prospective study to compare the incidene of different types of complications in local perforator flaps in reconstruction of forearm, wrist and hand skin defects in relation to different factors related to the patient as age, medical disorders, and smoking or related to the trauma as mode of injury or presence of associated injuries.

This study showed detailed data regarding age, sex, interval between trauma and coverage, description of associated injuries, and different types of complications which were included by details in this study which could be of great help for other studies.

In this study we assessed patients' satisfaction regarding donor site morbidity and aesthetic outcome of the flap as two separate items as shown in table (3) and we gave the patients 4 choices in the questionnaire, in contrast to Ignatiadis et al. ${ }^{(21)}$ and Jang et al. ${ }^{(28)}$ who gave their patients three choices only in the questionnaire, also they did not separate donor site from the flap itself during assessment of patients' satisfaction.

One of the limitations in this study, is the small sample size, larger sample size is needed to achieve more reliable results and to add to the statistical strength of the study.

Other limitation is that we did not compare the outcomes of propeller and free flaps, this needs another randomized study with larger sample size.

Other limitation is that we did not include any case of AIA perforator flap for coverage the skin defect in any of the cases but this may be attributed to site of the defects or that our experience was better with RA and UA perforator flaps.

\section{Conclusion:}

We found perforator flaps to be a reliable tool for upper extremity coverage, with a low rate of failure and secondary surgery. These flaps are particularly useful for covering small- and medium-sized defects in the distal one third of the forearm, wrist, and hand; and they represent a reliable and effective alternative to free flaps.

The main advantage of a perforator flap is that it does not require division of the underlying main vessel also, they provide a like with like reconstruction, with minimal morbidity at the donor site and no need for microvascular anastomosis.

\section{REFERENCES:}

1. Saint-Cyr M, Wong C, Schaverien M, et al. The perforasome theory: vascular anatomy and clinical implications. Plastic and Reconstructive Surgery, 2009; 124(5):15291544.

2. Griffin $M$, Hindocha $S$, Malahias $M$,et al. Flap decisions and options in soft tissue coverage of the upper limb. The open orthopaedics journal, 2014, 8, (Suppl 2: M3) 409-414.

3. Artiaco S, Battiston B and Colzani G. Perforator based propeller flaps in limb reconstructive surgery: clinical application and literature review. Biomed Res Int.2014; 2014:690649.

4. Sauerbier $M$ and Unglaub F. Perforator Flaps in the Upper Extremity, Clin Plastic Surg 37 (2010) 667-671.

5. Morris SF and Taylor GI. Predicting the survival of experimental skin flaps with the knowledge of the vascular architecture. Plast Reconstr Surg 1993; 92:1352-61.

6. Taylor GI and Palmer JH. The vascular territories (angiosomes) of the body: 
experimental study and clinical applications. Br J Plast Surg 1987; 40: 113-41.

7. Taylor GI, Corlett RJ, Caddy CM, et al. An anatomic review of the delay phenomenon. II. Clinical applications. Plastic and Reconstructive Surgery. 1992; 89 (3): 408418.

8. Teo TC. The Propeller flap concept. Clinics in Plastic Surgery. 2010; 37(4):615-626.

9. Tos $\mathrm{P}$, In nocenti $\mathrm{M}$, Artiaco $\mathrm{S}$, et al. Perforator-based propeller flaps treating loss of substance in the lower limb. Journal of Orthopaedics and Traumatology. 2011; 12 (2): 93-99.

10. Saint-Cyr M and Hong JP. Propeller perforator flaps in forearm and hand reconstruction. IFSSH Scientific Committee on Microsurgery, March 2014.

11. Sullivan T, Smith J, Kermode J, et al. Rating the burn scar. J Burn Care Rehabil 1990;11:256-260.

12. Georgescu AV, Matei I, Ardelean F, et al. Microsurgical nonmicrovascular flaps in forearm and hand reconstruction. Microsurgery. 2007; 27(5):384-394.

13. D. Lazzeri, G. M. Huemer, F. Nicoli, et al., "Indications, outcomes, and complications of pedicled propeller perforator flaps for upper body defects: a systematic review, "Archives of Plastic Surgery", 2013, vol.40, no.1, p.44.

14. Ono S, Sebastin SJ, Yazaki N, et al. "Clinical applications of perforator-based propeller flaps in upper limb soft tissue reconstruction", J Hand Surg,2011, vol.36, P.853.

15. Taylor GI and Palmer JH. Angiosome theory. Br J Plast Surg. 1992; 45:327-8.

16. Ono S, Sebastin SJ, Yazaki N, et al. "Clinical applications of perforator-based propeller flaps in upper limb soft tissue reconstruction", J Hand Surg, 2011, vol.36, P.860.

17. Andrew $M$ and James $C$, Radial Artery Peforator Flap, J Hand Surg, 2010;35A:307.

18. Thomsen J B, Gunnarsson G L, and Jackson $\mathrm{L} \mathrm{T}$, The freestyle pedicle perforator flap: a new favorite for the reconstruction of moderate-sized defects of the torso and extremities, Eur J Plast Surg. 2015; 38: 3136.

19. Zhang Y, Lazzeri D, Georg M. et al. Indications, Outcomes, and Complications of Pedicled Propeller Perforator Flaps for Upper Body Defects: A Systematic Review. Arch Plast Surg. 2013 Jan; 40 (1): 44-50.

20. Pignatti M, Pasqualini M, Governa M, Propeller flaps for leg reconstruction. J Plast Reconstr Aesthet Surg. 2008; 61:777-83.

21. Ignatiadis I A and Giannoulis F. Ulnar and radial artery based perforator adipofascial flaps, EEXOT, 2008; 59 (2):101-103.

22. Mahmoud WH: Radial forearm flap versus radial adipofascial perforator based flap for reconstruction of hand soft tissue defects, Donnish Journal of Medicine and Medical Sciences April 2015; 2 (3): 019-020.

23. D'Arpa S, Cordova A, Pignatti $M$, et al. Freestyle pedicled perforator flaps: safety, prevention of complications, and management based on 85 consecutive cases. Plastic and Reconstructive Surgery. 2011; 128 (4): 892-906.

24. Vitse J, Bekara F and Bertheuil N. Perforator-based propeller flaps reliability in upper extremity soft tissue reconstruction: a systematic review. J Hand Surg 2016; 42 (2): 157-164.

25. Pignatti $M$, Ogawa $R$, Hallock GG, et al. The "Tokyo" consensus on propeller flaps. Plast Reconstr Surg, 2011, 127 (2) :716722.

26. Pignatti M, D'Arpa $S$ and Cubison TCS. Novel fasciocutaneous flaps for the reconstruction of complicated lower extremity wounds. Techniques in Orthopaedics. 2009; 24(2):88-95.

27. Panse N, Sahasrabudhe P and Bhatt Y. Use of local perforator flaps for post burn reconstruction. Word J Plast Surg 2012; 1 (1): 22-26.

28. Jang $\mathrm{H}$ S, Lee $\mathrm{Y} H$ and $\operatorname{Kim} M \mathrm{~B}$, Fasciocutaneous propeller flap based on perforating branch of ulnar artery for soft tissue reconstruction of the hand and wrist. Clin Orthop Surg. 2018 Mar; 10 (1): 74-79. 
إعادة بناء فقدان الجلا باليد والرسغ والساعد عن طريق الثريحة الجلدية الموضعية المعتمدة علي

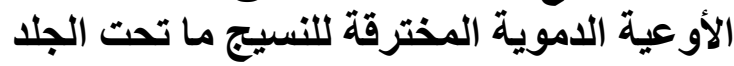

محمد مصطفى الماحي وأحمــ نعيم عطيـة ورامـــي أحمــد ديـاب وعمرو مصطفى محمد علي و حسن عبد الحميل عبد الفتاح

قسم جراحة العظام، كلية الطب، جامعةعين شمس علد

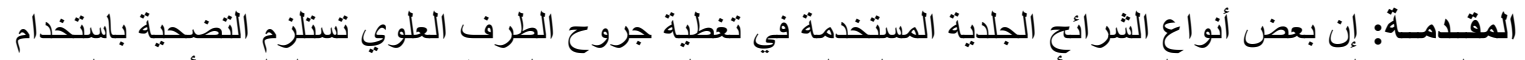

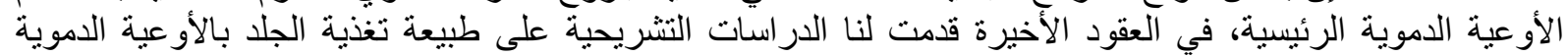

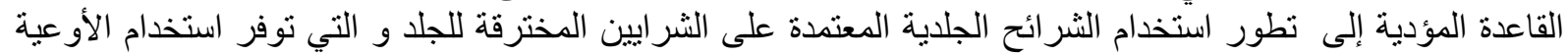
الأدوية الرئيسية.

الهدف من الدراسة: تقييم مدى فاعلية و كفاعة الثريحة الجلدية الموضعية المعتمدة علي الأوعية الدموية المخترقة

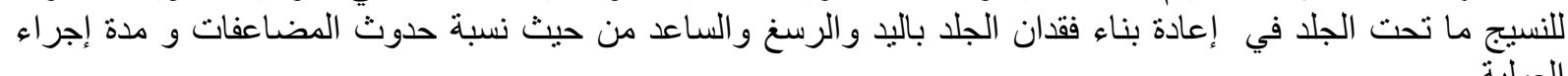

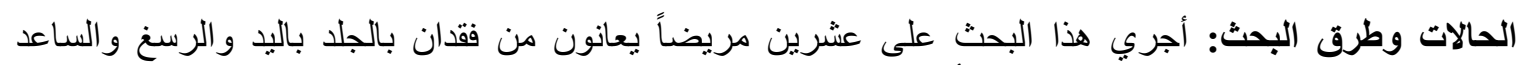

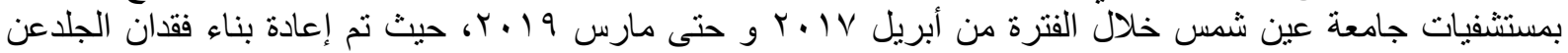

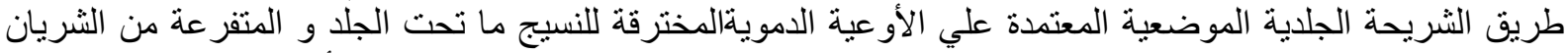

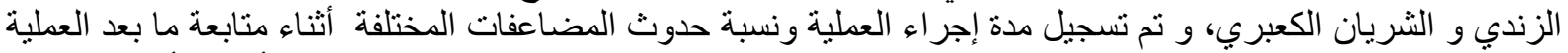
و تم تقييم نتائج العملية من الناحية الجمالية و ذلك بقياس مدى رضئ رضا المرضى عن طريق استطلاع رأي يملأ بو اسطتهم و عن طريق مقياس العالم فانكوفر لتقييم الندبات

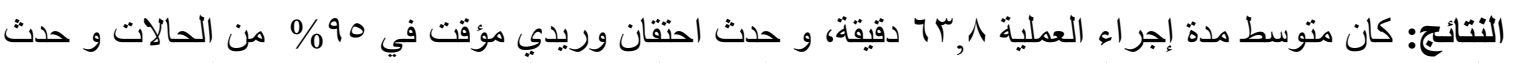

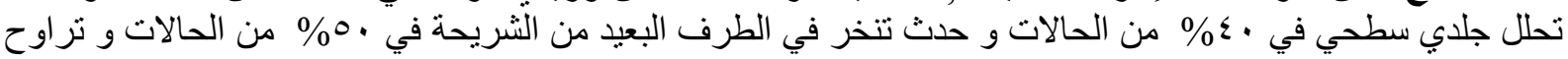

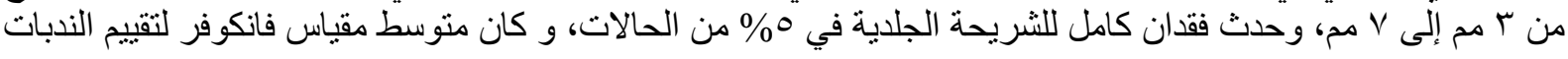
$.0,10$

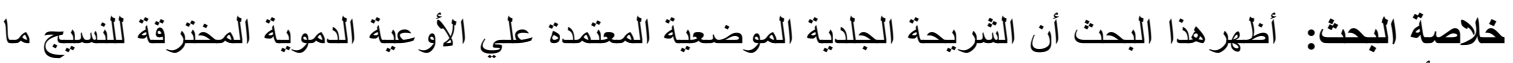

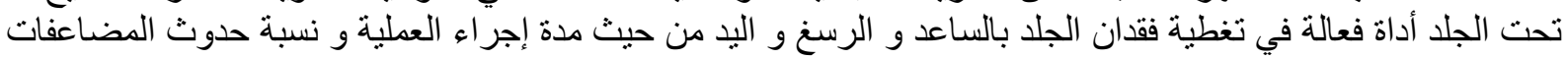

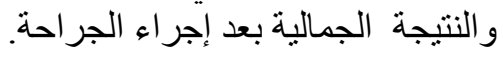

